\title{
Correlation of black carbon aerosol and carbon monoxide in the high-altitude environment of Mt. Huang in Eastern China
}

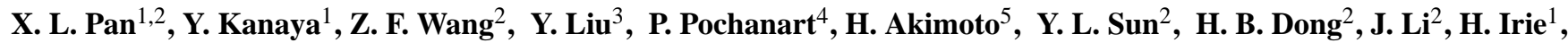 \\ and M. Takigawa ${ }^{1}$ \\ ${ }^{1}$ Research Institute for Global Change, Japan Agency for Marine-Earth Science and Technology, Japan \\ ${ }^{2}$ State Key Laboratory of Atmospheric Boundary Layer Physics and Atmospheric Chemistry, Institute of Atmospheric \\ Physics, Chinese Academy of Sciences, Beijing, China \\ ${ }^{3}$ Institutes of Atmospheric Physics, Chinese Academy of Sciences, Beijing, China \\ ${ }^{4}$ School of Social and Environmental Development, National Institute of Development Administration, Bangkok, Thailand \\ ${ }^{5}$ Acid Depositions and Oxidant Research Center, Asia Center for Air Pollution Research, Japan
}

Received: 6 January 2011 - Published in Atmos. Chem. Phys. Discuss.: 8 February 2011

Revised: 9 August 2011 - Accepted: 17 August 2011 - Published: 20 September 2011

\begin{abstract}
Understanding the relationship between black carbon (BC) and carbon monoxide (CO) will help improve BC emission inventories and the evaluation of global/regional climate forcing effects. In the present work, the BC $\left(\mathrm{PM}_{1}\right)$ mass concentration and $\mathrm{CO}$ mixing ratio were continuously measured at a high-altitude background station on the summit of Mt. Huang $\left(30.16^{\circ} \mathrm{N}, 118.26^{\circ} \mathrm{E}\right.$, 1840 ma.s.1.). Annual mean BC mass concentration was $1004.5 \pm 895.5 \mathrm{ng} \mathrm{m}^{-3}$ with maxima in spring and autumn, and annual mean $\mathrm{CO}$ mixing ratio was $424.1 \pm 159.2 \mathrm{ppbv}$. A large increase of $\mathrm{CO}$ was observed in the cold season, implying the contribution from the large-scale domestic coal/biofuel combustion for heating. The BC-CO relationship was found to show different seasonal features but strong positive correlation $(R>0.8)$. In Mt. Huang area, the $\triangle \mathrm{BC} / \triangle \mathrm{CO}$ ratio showed unimodal diurnal variations and had a maximum during the day (09:00-17:00 LST) and minimum at night (21:00-04:00 LST) in all seasons, indicating the impact of planetary boundary layer and the intrusion of clean air masses from the high troposphere. Back trajectory cluster analysis showed that the $\Delta \mathrm{BC} / \Delta \mathrm{CO}$ ratio of plumes from the Eastern China (Jiangsu, Zhejiang provinces and Shanghai) was $8.8 \pm 0.9 \mathrm{ng} \mathrm{m}^{-3} \mathrm{ppbv}^{-1}$. Transportation and industry were deemed as controlling factors of the $\mathrm{BC}$ $\mathrm{CO}$ relationship in this region. The $\triangle \mathrm{BC} / \triangle \mathrm{CO}$ ratios for air masses from Northern China (Anhui, Henan, Shanxi and Shandong provinces) and southern China (Jiangxi, Fujian
\end{abstract}

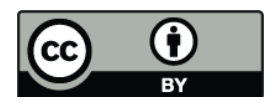

Correspondence to: X. L. Pan (xlpanelf@gmail.com) and Hunan provinces) were quite similar with mean values of $6.5 \pm 0.4$ and $6.5 \pm 0.2 \mathrm{ng} \mathrm{m}^{-3} \mathrm{ppbv}^{-1}$ respectively. The case studies combined with satellite observations demonstrated that the $\triangle \mathrm{BC} / \triangle \mathrm{CO}$ ratio for biomass burning (BB) plumes were $10.3 \pm 0.3$ and $11.6 \pm 0.5 \mathrm{ng} \mathrm{m}^{-3} \mathrm{ppbv}^{-1}$, significantly higher than those during non-BB impacted periods. The loss of $\mathrm{BC}$ during transport was also investigated on the basis of the $\Delta \mathrm{BC} / \Delta \mathrm{CO}-\mathrm{RH}$ (relative humidity) relationship along air mass pathways. The results showed that BC particles from Eastern China area was much more easily removed from atmosphere than other inland regions due to the higher RH along transport pathway, implying the importance of chemical compositions and mixing states on $\mathrm{BC}$ residence time in the atmosphere.

\section{Introduction}

Black carbon (BC) is an important component of atmospheric aerosols and a short-lived climate forcing agent, and it is mostly produced by the incomplete combustion of fossil fuels and bio-fuels used for energy (Bond et al., 2004). Industrial and residential mobile resources as well as biomass burning account for to its major emissions. Suspended BC could disturb the vertical temperature distribution in the atmosphere by absorbing more solar radiation (Babu et al., 2002; Chung and Seinfeld, 2005; Badarinath and Latha, 2006), and it also serves as cloud condensation nuclei and thus alters cloud properties (e.g., color, formation, life span, and albedo) and affects the level of radiation reaching the surface (Conant et al., 2002; Nenes et al., 2002; Cozic et

Published by Copernicus Publications on behalf of the European Geosciences Union. 
al., 2008; Kuwata et al., 2009; Liu et al., 2009). Fine-mode $\mathrm{BC}$ particles increase the regional atmospheric opacity (Seinfeld, 2008) and have detrimental health effects (Oberdörster and Yu, 1990). Severe environmental problems such as the acceleration of glacier melting have been found to be associated with BC deposition on snow surfaces (Ming et al., 2008; Ramanathan and Carmichael, 2008; Ming et al., 2009; Thevenon et al., 2009). Recently, observations and modeling have increasingly suggested a relatively strong positive climate forcing effect of black carbon. $\mathrm{BC}$ forcing at the top-ofatmosphere was estimated to be as much as $55 \%$ of the $\mathrm{CO}_{2}$ forcing with a mean value of $0.9 \mathrm{~W} \mathrm{~m}^{-2}$ (and range from 0.4 to $1.2 \mathrm{~W} \mathrm{~m}^{-2}$ ) (Ramanathan and Carmichael, 2008). The extent of BC-induced warming is highly determined by the atmospheric loading of soot particle mass concentrations (Sato et al., 2003), sulfate and organic coatings (Ramana et al., 2010), their shapes (Adachi et al., 2010) and mixing state (Jacobson, 2001; Schwarz et al., 2008; Naoe et al., 2009).

Significant emissions of pollutants (e.g., BC and CO) in East Asia due to ever-quickening industrial development, surging automobile ownership, and intensive seasonal burning of biomass are well known (Streets et al., 2001; Bond et al., 2004; Streets and Aunan, 2005; Zhang et al., 2009). Bottom-up statistical methods, widely used to investigate regional emission inventories (Streets et al., 2001; Cao et al., 2006; Ohara et al., 2007), indicate that more than onefourth of $\mathrm{BC}$ originates from China; however, variations in the emission strengths of different fuel types and combustion conditions produce large uncertainties (Bond et al., 2004). Long-term measurements of BC in highly polluted and remote areas are of importance for a better estimating regional characteristics (Wang et al., 2006) and constraining the highly uncertain emission rate of BC (Kondo et al., 2006; Han et al., 2009). Carbon monoxide (CO) is another byproduct of the incomplete oxidation. A remarkable correlation between $\mathrm{BC}$ and $\mathrm{CO}$ has been found in a number of studies (Jennings et al., 1996; Derwent et al., 2001; Badarinath et al., 2007; Spackman et al., 2008), which make $\Delta B C / \Delta C O$ (BC minus background $\mathrm{BC}$, and $\mathrm{CO}$ minus background $\mathrm{CO}$ ) as a good indicator both for distinguishing different pollutant sources in case studies (Kondo et al., 2006; Spackman et al., 2008; Han et al., 2009; Subramanian et al., 2010) and validating BC emission inventories for models (Derwent et al., 2001; Dickerson et al., 2002). In present work, we mainly focus on the BC-CO relationships from anthropogenic sources in Eastern China (Sect. 4) based on concurrently measured $\mathrm{BC}$ and $\mathrm{CO}$ mass concentrations at Mt. Huang. Seasonal and diurnal variations of $\mathrm{BC}$ and $\mathrm{CO}$ (Sect. 3) are reported, and the impact of biomass burning on BC-CO relationship (Sect. 5), and factors affecting BC-CO relationship (Sect. 6) are discussed. Photochemical production of $\mathrm{CO}$ through oxidation of $\mathrm{CH}_{4}$ and other volatile organic compounds, comparatively smaller than direct anthropogenic emissions in East Asia, would not be addressed in this study.

\section{Experimental}

\subsection{Site description and meteorology}

$\mathrm{BC}$ and $\mathrm{CO}$ concentrations were continuously measured at a meteorological station on the summit of Mt. Huang $\left(30.16^{\circ} \mathrm{N}, 118.26^{\circ} \mathrm{E}, 1840 \mathrm{~m}\right.$ a.s.l., Anhui province). The site is located at the southern edge of the North China Plain, a heavy polluted region owing to its intense industrial/residential activities ( $\mathrm{Li}$ et al., 2008) and open burning of biomass during harvest seasons (Yamaji et al., 2010). Pollution emitted from the Yangtze River Delta metropolis clusters (about $200 \mathrm{~km}$ to the northeast) was also easily transported to the site with the prevailing northeast wind. According to the NASA INTEX-B emission inventory (Zhang et al., 2009), about $4585 \mathrm{Gg} \mathrm{yr}^{-1} \mathrm{PM}_{2.5}, 607 \mathrm{Gg} \mathrm{yr}^{-1} \mathrm{BC}$ and $61210 \mathrm{Gg} \mathrm{yr}^{-1} \mathrm{CO}$ were emitted in 2006 via anthropogenic activity in the region of the North China Plain, accounting for more than $35 \%$ of total emissions in China. According to bottom-up statistical techniques, emission of $\mathrm{BC}$ and $\mathrm{CO}$ were usually constructed on the basis of energy consumptions from different economic sectors and available experimental emission factors (Streets et al., 2001; Cao et al., 2006; Zhang et al., 2009). A map of $\Delta \mathrm{BC} / \Delta \mathrm{CO}$ ratio for East China was shown in Fig. 1. Other considerations in the site selection were that the region was uninhabited, the surrounding $1500 \mathrm{~km}^{2}$ had over $80 \%$ vegetation coverage of deciduous/coniferous mixed forest and grass, and local-source pollution produced by tourists was very limited. Mt. Huang has a subtropical monsoon climate, distinct seasons and abundant rainfall in summer (peaking in July). According to statistical analysis of 48-hour air mass back trajectories (Hysplit4 version $4.9 \mathrm{u}$, http://ready.arl.noaa.gov/HYSPLIT.php), about $38 \%, 45 \%$ and $17 \%$ of air mass were from northerly (NE$\mathrm{W}$ section), southerly (W-ESE section) and easterly (ESENE section) directions, respectively. This obvious difference in air mass pathways allowed investigation of the origins and transport of pollutants.

\subsection{Measurements and error analysis}

BC mass concentration was measured at 1 min time intervals using a multiple-angle absorption photometer (MAAP, Model 5012, Thermo Inc.). Air samples drawn from the ambient atmosphere passed through a $5 \mathrm{~m}$ long, 0.5 inch wide conductive tube and a $\mathrm{PM}_{1}$ cyclone (cut-off diameter of $1 \mu \mathrm{m}$, URG-2000-30EHB, USA). Assuming the BC massequivalent diameter (MED) had a log-normal distribution in the fine mode with a peak around $200 \mathrm{~nm}$ (Subramanian et al., 2010), the loss of BC particles (greater than $1 \mu \mathrm{m}$ in diameter) was estimated at less than $10 \%$ of the BC mass (Kanaya et al., 2008; Spackman et al., 2008; Kondo et al., 2009). The instrument operated by simultaneously measuring the optical attenuation and reflection of particles deposited on a glass fibrous filter from several detection angles. Here we used a 


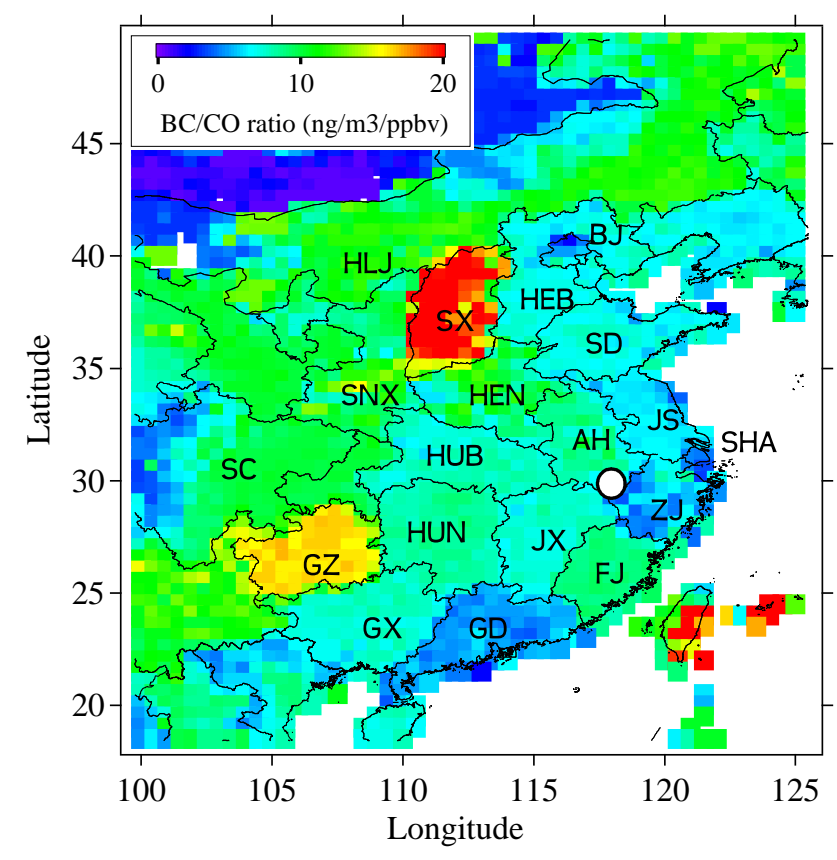

Fig. 1. Spatial distribution of $\Delta \mathrm{BC} / \Delta \mathrm{CO}$ ratio with grid resolution of $\left(0.5^{\circ} \times 0.5^{\circ}\right)$ from INTEX-B anthropogenic emission inventory. The black circles indicate the location of the observation site. Correspondingly $\triangle \mathrm{BC} / \Delta \mathrm{CO}$ ratios are converted from $\mathrm{Gg} \mathrm{Gg}^{-1}$ to $\mathrm{ng} \mathrm{m}^{-3} \mathrm{ppbv}^{-1}$ by assuming that in Standard Temperature and Pressure condition. Abbreviations in the plot are BJ (Beijing), HEB (Hebei), SX (Shanxi), SD (Shandong), HEN (Henan), JS (Jiangsu), SNX (Shaanxi), HUB (Hubei), SC (Sichuan), SH (Shanghai), AH (Anhui), HUN (Hunan), JX (Jiangxi), ZJ (Zhejiang), FJ (Fujian), GD (Guangdong), GX (Guangxi), and GZ (Guizhou).

fixed $\sigma_{\text {ap }}$ value of $6.6 \mathrm{~m}^{2} \mathrm{~g}^{-1}$ at $637 \mathrm{~nm}$ to convert the absorption coefficient to mass concentration following the manufacture's recommendations. Although the calculation for the present instrument (MAAP) already took into account corrections for removing the multi-scattering effect, this techniques could still overestimated the $\mathrm{BC}$ mass concentration by $5-50 \%$ due to coating effects of non-absorbing particles on soot particles (Hitzenberger et al., 2006; Slowik et al., 2007; Chow et al., 2009). The largest discrepancy has been found to be associated with the contributions of "brown carbon" (Reisinger et al., 2008). According to inter-comparison experiments performed at a high mountain site over central Eastern China (Kanaya et al., 2008), the MAAP-measured BC mass concentration in fine mode $(<1 \mu \mathrm{m})$ was approximately the same as that measured by the particle soot absorption photometer (PSAP, Radiance Research, with inlet heated at $400^{\circ} \mathrm{C}$ ). Nevertheless, the concentration was approximately $40 \%$ higher than that obtained using an ECOC semi-continuous analyzer (Sunset Laboratory, USA, NIOSH protocol). We divided the all $\mathrm{BC}$ data with a factor of 1.4 in converting the MAAP-measured $\mathrm{BC}$ mass concentration to an "EC" category. Therefore the expression of "BC" from our observation was exactly referred to $\mathrm{EC}_{\mathrm{a}}$ which operationally defined as the fraction of carbon that is oxidized above a certain temperature threshold in the presence of an oxygen containing atmosphere (Andreae and Gelencsér, 2006). Studies carried out in Tokyo (Kondo et al., 2006) showed that mass concentrations based on the NIOSH protocol were about $20 \%$ less than those based on the IMPROVE protocol, and the uncertainty in the absorbance determined using the MAAP was estimated to be $12 \%$ (Petzold et al., 2005); therefore, the overall uncertainty was about $25 \%$.

In situ measurement of the $\mathrm{CO}$ mixing ratio was carried out with a commercial gas filter non-dispersive infrared $\mathrm{CO}$ gas analyzer (Thermo Scientific. Model 48C, USA, time resolution of $1 \mathrm{~min}$; detection limit: $30 \mathrm{ppbv}$ for a 2-min average) equipped with a Nafion dryer to reduce interference by water vapor in the sampled air. The zero point (baseline of the instrumental signal) was routinely checked in the first 10 min of each hour using purified air, and span calibrations were performed in the ambient environment before (May 2006) and in the middle of the field experiments (December 2007) by injecting standard span gas (1.04 parts per million by volume (ppmv), produced by Nissan-Tanaka Corp., Japan). The difference between the span and zero points demonstrated that the measured $\mathrm{CO}$ mixing ratio was about $46 \mathrm{ppbv}$ higher than the standard value, and the ratio was adjusted by $95 \%$ afterward. The instrument baseline in the observation period has a stable linear increasing trend with a drift ratio of $0.4 \mathrm{ppbh}^{-1}$; however, this influence was easily removed by zero-point-deduction operations in subsequent data procedures. The overall uncertainty was estimated to be $5 \%$. Additional meteorological parameters (wind, $\mathrm{RH}$ and temperature) were acquired from the NCEP reanalysis dataset (ftp://ftp.cdc.noaa.gov/Datasets/ncep.reanalysis/ surface/) with a time interval of $6 \mathrm{~h}$ at the site grid.

\section{$3 \mathrm{BC}$ and $\mathrm{CO}$ temporal variations}

\subsection{Seasonal variations}

A data set comprising approximately 3 years (from 1 June 2006 to 14 May 2009) of BC mass concentrations and over 1 years (from 25 January 2007 to 25 May 2008) of CO mass concentrations was reported here. $\mathrm{BC}$ and $\mathrm{CO}$ concentrations show large variations with means of $1004.5 \pm 895.5 \mathrm{ng} \mathrm{m}^{-3}$ and $424.1 \pm 159.2 \mathrm{ppbv}$, respectively for the entire observation period. The hourly mean data show that atmospheric BC loading was high (over $2000 \mathrm{ng} \mathrm{m}^{-3}$ ) mostly in spring and autumn, and the $\mathrm{CO}$ concentration was high (over $1000 \mathrm{ppbv}$ ) in winter when large amount of biofuel (biomass and agriculture residues) were consumed for residential heating in urban area over North China. Figure 2 illustrates monthly variations of $\mathrm{BC}$ and $\mathrm{CO}$ concentrations. The $\mathrm{CO}$ concentration generally had a winter maximum and summer minimum, and varied greatly in winter owing to the frequent 
shifting of air masses from the clean continent interior and heavily polluted urban plumes in the heating period (normally from November to March in Northern China). In summer, the $\mathrm{CO}$ concentration in the Mt. Huang region apparently decreased owing to frequent intrusions of clean air mass from the Pacific Ocean, and this seasonal trend was confirmed by observations in Eastern China made by MOPITT (http://www.acd.ucar.edu/mopitt/). A slight reduction in the $\mathrm{CO}$ concentration with large variations in November might relate to the uncertainty of having a limited number of data $(N=720)$ because no obvious changes in pollutant emissions were expected for that season. Seasonal variations in the $\mathrm{BC}$ loading show a bimodal distribution with two enhancement periods of BC loading in May and October, consistent with the large-scale burning of crop residues in these two months. The exacerbation of $\mathrm{BC}$ pollution probably resulted from the combustion of biomasses. Considering the regional climatology, the increase in the $\mathrm{BC}$ concentration was also related to the dynamic transport and planetary boundary layer (PBL) evolution characteristics in the transitional periods of the summer monsoon (May) and winter monsoon (October). In summer (from June to August), the $\mathrm{BC}$ concentration decreased to $319.5( \pm 225.0) \mathrm{ng} \mathrm{m}^{-3}$, and back trajectory analysis indicated that more than $80 \%$ of air mass in that season came from southern China where the BC emission was relatively weak than north China plain (Streets et al., 2001; Cao et al., 2006, 2009; Chen et al., 2009). Wet removal was another key factor of $\mathrm{BC}$ declination, albeit there was summer strong thermal vertical convection and the full development of the PBL, which was favorable for uplifting surface pollutants to the high-altitude environment. In winter and spring, monthly mean $\mathrm{BC}$ mass concentrations were relatively stable with a mean value of $486.9 \mathrm{ng} \mathrm{m}^{-3}$ the large variations (standard deviation of $372.4 \mathrm{ng} \mathrm{m}^{-3}$ ) mostly resulted from meteorology (PBL stratification, turbulence and transportation) and regional pollutant emissions in surrounding regions.

\subsection{Diurnal variations}

Diurnal variations in $\mathrm{BC}, \mathrm{CO}$ and $\triangle \mathrm{BC} / \Delta \mathrm{CO}$ at observation site in dry condition $(\mathrm{RH}<40 \%)$ were shown in Fig. 3. As expected, BC showed pronounced unimodal distributions with generally higher concentrations in the afternoon (1200 1600 Local Standard Time (LST)) owing to the development of the PBL and pollution lifting with the valley breeze during the day; the BC concentrations in the daytime (09:00-16:00 LST) were $\quad 1359.4 \pm 801.8 \mathrm{ng} \mathrm{m}^{-3}, \quad 961.9 \pm 438.9 \mathrm{ng} \mathrm{m}^{-3}$, $1662.8 \pm 918.7 \mathrm{ng} \mathrm{m}^{-3}$ and $1300.3 \pm 1179.9 \mathrm{ng} \mathrm{m}^{-3}$ respectively for spring (March-May), summer (June-August), autumn (September-November) and winter (December, January and February), respectively as shown in Fig. 3a. With suppression of the PBL at night (18:00 06:00 LST), the $\mathrm{BC}$ concentrations at the site decreased to $1164.0 \mathrm{ng} \mathrm{m}^{-3}$

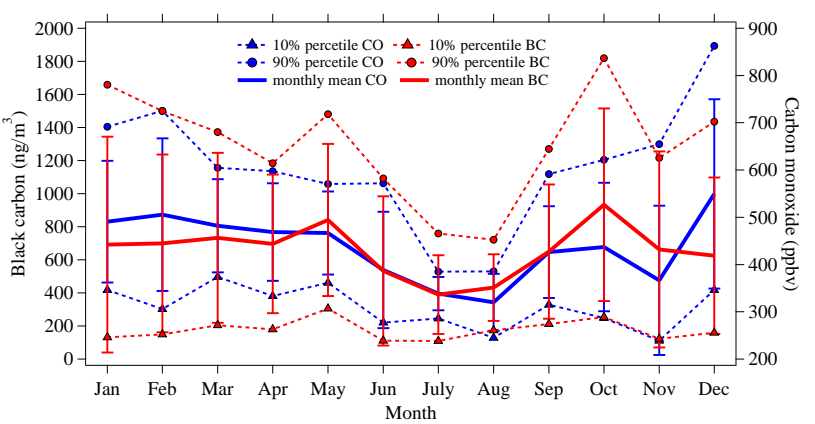

Fig. 2. Seasonal variations in $B C$ (red) and $C O$ (blue) concentrations during the observation period. Circles and triangles represent $90 \%$ and $10 \%$ percentiles of hourly mean BC and CO concentrations respectively. Error bars are also plotted in the figure to indicate monthly variations.

on average in spring, autumn and winter and $822.9 \mathrm{ng} \mathrm{m}^{-3}$ in summer. This pattern was different from that in the urban area where higher $\mathrm{BC}$ and $\mathrm{CO}$ concentrations reach to maximum in the early morning due to the traffic emissions and shallow boundary layer. In winter the $\mathrm{BC}$ concentration peaked earlier at approximately 1500 LST, and decreased quickly afterward owing to the short duration of sunshine. Diurnal variations in CO have seasonal features. As shown in Fig. 3b, fluctuations in the CO concentration were weaker in winter and summer than in other seasons; the mean mixing ratios were $426.4 \pm 29.4$ and $354.7 \pm 23.1 \mathrm{ppbv}$ respectively. As seen in the figure, relatively high $\mathrm{CO}$ atmosphere loadings in winter time was observed, which might be due to large-scale fossil fuels burning for heating in Northern China. In summer the stable and lower CO loading were strongly related to the strong mixing of clean air masses from marine regions and urban plumes within the PBL. In autumn, the CO concentration increased obviously from $332.3 \pm 167.0 \mathrm{ppbv}$ at night (18:00-06:00 LST) to a maximum $(473.7 \pm 214.2 \mathrm{ppbv})$ in the afternoon (17:00 LST)

The correlation of $\mathrm{BC}-\mathrm{CO}$ indicated pollution from certain source categories. In this study, the $\triangle \mathrm{BC} / \Delta \mathrm{CO}$ ratio was derived using the equation $\left(\mathrm{BC}-\mathrm{BC}_{0}\right) /\left(\mathrm{CO}-\mathrm{CO}_{0}\right) . \mathrm{CO}_{0}$ (baseline concentrations of $\mathrm{CO}$ ) were determined as values of the 1.25 percentile of data for spring, summer, autumn and winter, and the results were 109.21, 118.71, 90.81 and $116.1 \mathrm{ppbv}$ for $\mathrm{CO}_{0}$ respectively. This criterion was applied to investigate the $\triangle \mathrm{BC} / \triangle \mathrm{CO}$ variations in Tokyo, and also Beijing (Kondo et al., 2006; Han et al., 2009). $\mathrm{BC}_{0}$, the background of $\mathrm{BC}$ concentration was assumed as zero. The $\triangle \mathrm{BC} / \triangle \mathrm{CO}$ ratio had an approximately unimodal diurnal distribution (Fig. 3c). The $\Delta \mathrm{BC} / \Delta \mathrm{CO}$ ratios were on average 4.2, 3.7, 4.6 and $3.7 \mathrm{ng} \mathrm{m}^{-3} \mathrm{ppbv}^{-1}$ for spring, summer, autumn and winter respectively. Seasonally, the relatively higher $\triangle \mathrm{BC} / \triangle \mathrm{CO}$ ratio in autumn was owing to burning of biomass in harvest season (Fig. 3b). The diurnal 

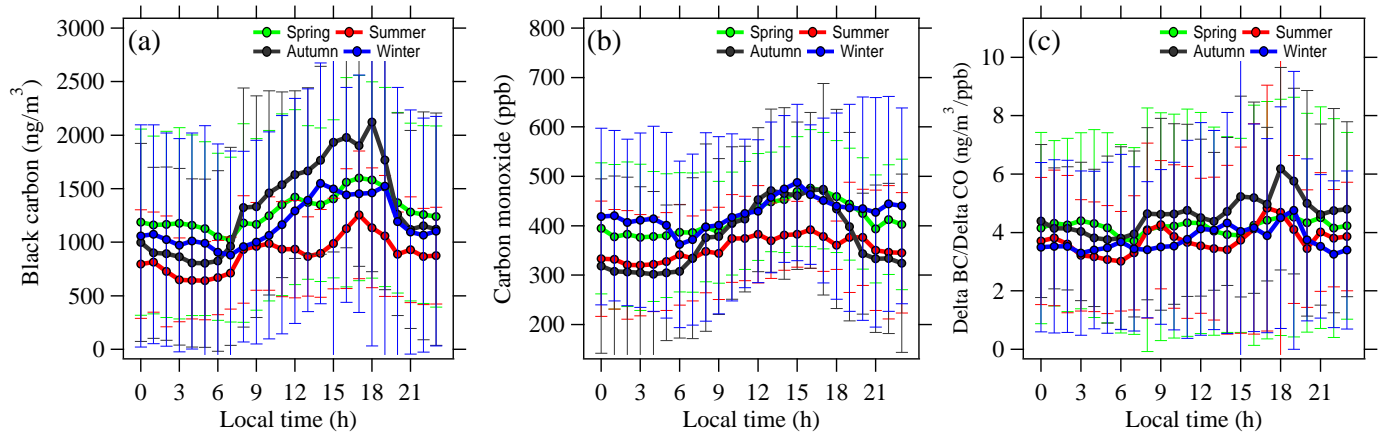

Fig. 3. Diurnal variations of $\mathrm{BC}, \mathrm{CO}$ and $\Delta \mathrm{BC} / \Delta \mathrm{CO}$ for spring, summer, fall and winter time. In the plot, only data with $\mathrm{RH}$ less than $40 \%$ at observation site are taken into considerations. Spring comprises March, April and May; summer comprises June, July and August; autumn comprises September, October and November; and winter comprises December, January, February.

variations of $\Delta \mathrm{BC} / \Delta \mathrm{CO}$ at urban sites were quite different from this study. In Beijing a high $\Delta \mathrm{BC} / \Delta \mathrm{CO}$ ratio peak (approximately $8 \mathrm{ng} \mathrm{m}^{-3} \mathrm{ppbv}^{-1}$ in the very early morning) was observed due to increased emission from heavy vehicles with diesel engines (Kondo et al., 2006; Han et al., 2009). With gradually cease of heavy duty transportation activities in the urban site and increase of gasoline engine vehicles, $\Delta \mathrm{BC} / \Delta \mathrm{CO}$ ratio gradually decreased till $\sim 14: 00 \mathrm{LT}$ in the afternoon. On the contrary, $\Delta \mathrm{BC} / \Delta \mathrm{CO}$ ratio at Mt. Huang was relatively lower at night owing to intrusion of clean air from the tropopause, and increasing with the development of PBL which transport pollution upwardly at day time. The $\triangle \mathrm{BC} / \triangle \mathrm{CO}$ ratio measured at top of mountain was almost well mixed from different emission sources owing to convections.

\section{Cluster analysis of regional BC and $\mathrm{CO}$ correlations}

To investigate the relationship between the $\Delta \mathrm{BC} / \Delta \mathrm{CO}$ ratio and the origin of the air mass, 48-hour back trajectory analysis was performed with ensemble approach. For each hour 27 back trajectories with horizontal offset of 1 grid and vertical shift of 0.01 in sigma unit were calculated in the meantime. Input meteorological fields were produced by NCEP Global Data Assimilation System (GDAS) model for four times a day at 00:00, 06:00, 12:00 and 18:00 UTC, the grid resolution was $1^{\circ} \times 1^{\circ}$. To eliminate the effect of local wet removal, only BC data for which ambient RH was less than $40 \%$ for their entire air mass pathway were included in the calculations. Normally emission at surface was of particular interest, therefore only the back trajectories passed through mixing layer (determined by Hysplit model), were applied into cluster calculations. Furthermore we also removed the period when number of hotspots detected by MODIS satellite over 10 in the footprint regions. All back trajectory air mass pathways were grouped into three clusters. Cluster \#1 indicated air masses from north China and moved across heavily polluted regions in Shanxi, Hebei, Henan and Shan- dong provinces (Fig. 4a); air masses in Cluster \#2 mainly came from eastern sector and passed through densely populated urban area in Eastern China regions (Jiangsu, Zhejiang provinces and Shanghai, Fig. 4b). Cluster \#3 comprised the air masses originated from southern of China (Jiangxi, Fujian and Hunan provinces, Fig. 4c). In Fig. 4, cities with population over 1 million were also presented for each cluster, and the size of circles was proportional to the yearly mean $\mathrm{PM}_{10}$ mass concentrations which derived from daily API values for 85 Chinese cities using the government-published routine method as described by Qu et al. (2010).

BC-CO correlations for each cluster were shown in Fig. 4d. Tight correlations between $\mathrm{BC}$ and $\mathrm{CO}$ were observed for all clusters $(R=0.87$ for Cluster \#1, 0.94 for Cluster \#2 and 0.90 for Cluster \#3). BC-CO relationship highly depended on sources and sinks in the context of pollution transportation, and the $\Delta \mathrm{BC} / \triangle \mathrm{CO}$ ratio reported here was regionally representative on the basis of four considerations. (1) A dry deposition velocity of less than $1 \mathrm{~mm} \mathrm{~s}^{-1}$ was documented for sub-micron aerosol particles (MED of BC typically ranges $200-600 \mathrm{~nm}$ ), suggesting a removal rate of about $10 \%$ per day (Derwent et al., 2001), which was within the overall uncertainty of the MAAP instrument. CO could be well conserved in the atmosphere with the life time of $\sim 1$ month against oxidation by $\mathrm{OH}$. (2) For $\mathrm{BC}$ aging processes (e.g., oxidation, condensation and coagulation in the atmosphere), which dominated solubility and thus the removal rate of $\mathrm{BC}$ particles, modeling studies have suggested an exponential lifetime of 40-80 h (Cooke and Wilson, 1996). Croft et al. suggested a conversion timescale of 4.9 days for altering hydrophobic BC to hydrophilic/mixed BC through physical and oxidation processes (Croft et al., 2005). Here we filtered the data according to the criterion of $\mathrm{RH}(<40 \%)$ conditions at which aerosol hygroscopicity was very weak even when aerosols were coated by sulfate and nitrate substances (Pan et al., 2009). (3) Baumgardner et al. (2002) and Subramanian et al. (2010) suggested that ambient air dilution and dispersion should not appreciably alter the ratio of the 

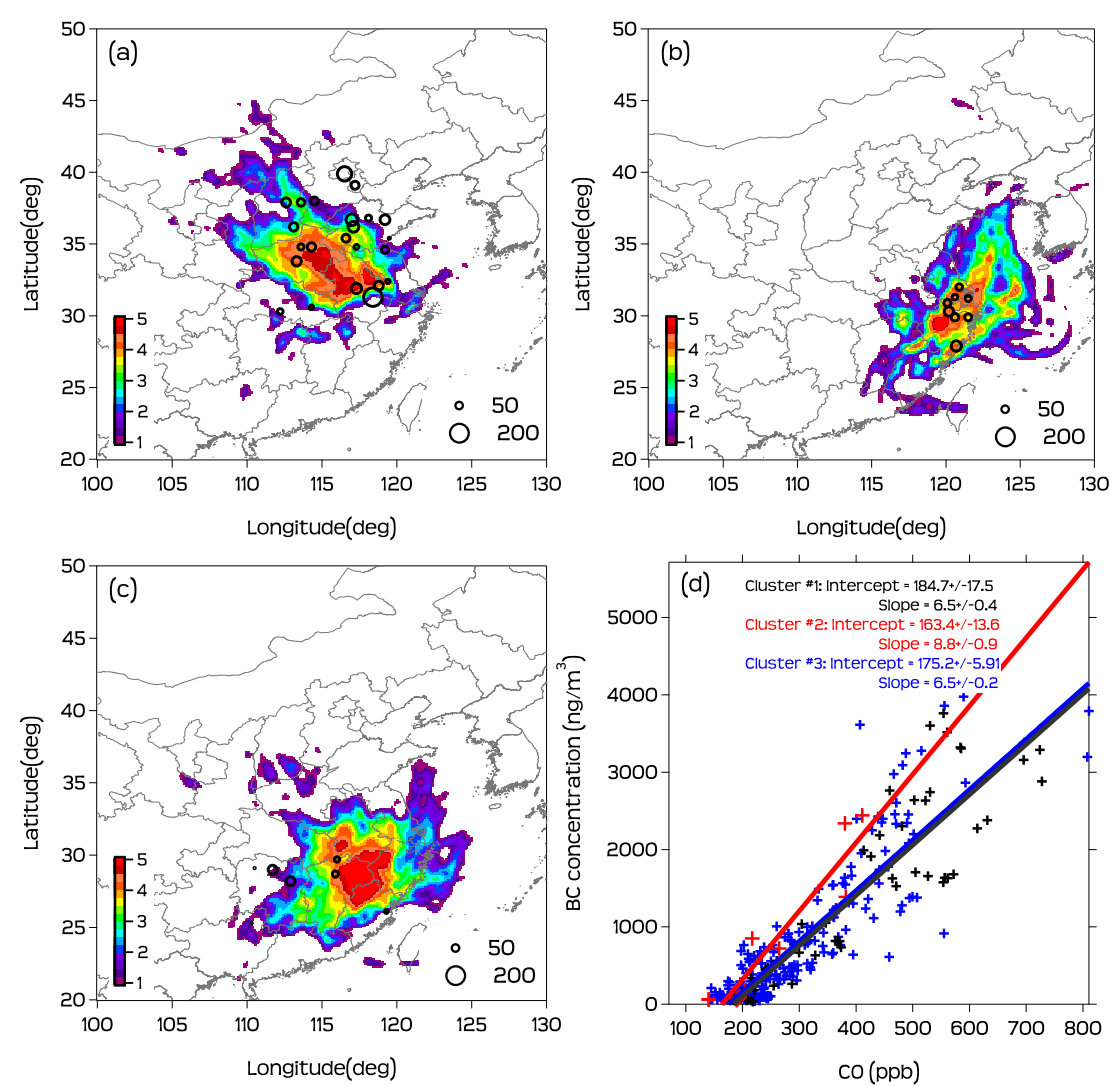

Fig. 4. Footprint regions of air masses 48-h back trajectories using ensemble approach (a, b, $\mathbf{c}$ ) and a scatter plot of the BC-CO correlation for each cluster (d). Shading colors (unit: natural logarithm of residence hour in each grid) in the plots indicate the possible source region of pollution. The size of circle represents the yearly mean $\mathrm{PM}_{10}$ mass concentration for the metropolis (population over 1 million) included in the footprint region.

Table 1. Statistical results of $\mathrm{BC}$ and $\mathrm{CO}$ concentrations and $\mathrm{BC}-\mathrm{CO}$ correlations for each cluster.

\begin{tabular}{|c|c|c|c|c|c|c|c|c|}
\hline \multirow[t]{2}{*}{$\begin{array}{l}\text { Cluster } \\
\text { category }\end{array}$} & \multicolumn{2}{|c|}{$\begin{array}{c}\mathrm{BC} \\
\left(\mathrm{ng} \mathrm{m}^{-3}\right)\end{array}$} & \multicolumn{2}{|c|}{$\begin{array}{c}\mathrm{CO} \\
\text { (ppbv) }\end{array}$} & \multirow[t]{2}{*}{$\begin{array}{r}\Delta \mathrm{BC} / \Delta \mathrm{CO}^{\mathrm{a}} \\
\left(\mathrm{ng} \mathrm{m}^{-3} \mathrm{ppbv}^{-1} \text { ) }\right.\end{array}$} & \multirow[t]{2}{*}{$\begin{array}{r}\text { intercepts } \\
(\mathrm{ppbv})\end{array}$} & \multirow[t]{2}{*}{$\mathrm{R}^{\mathrm{b}}$} & \multirow[t]{2}{*}{$\mathrm{N}^{\mathrm{c}}$} \\
\hline & mean & S.D & mean & S.D & & & & \\
\hline \#1 & 1357.0 & 1173.5 & 395.6 & 161.9 & $6.5 \pm 0.4$ & $184 . \pm 17.5$ & 0.90 & 3660 \\
\hline \#2 & 645.1 & 877.4 & 237.0 & 84.7 & $8.8 \pm 0.9$ & $163.4 \pm 13.6$ & 0.94 & 1860 \\
\hline \#3 & 740.9 & 849.0 & 285.8 & 122.8 & $6.5 \pm 0.2$ & $175.2 \pm 5.91$ & 0.87 & 14520 \\
\hline
\end{tabular}

${ }^{\mathrm{a}}$ values are written as mean $\pm 3 \sigma,{ }^{\mathrm{b}}$ at the $95 \%$ significance level, ${ }^{\mathrm{c}}$ number of one-minute averaged data

two species near the source region despite the different thermal velocities and diffusion coefficients of BC and CO. (4) $\mathrm{BC}$ and $\mathrm{CO}$ from different emissions were well mixed during $48 \mathrm{~h}$ of convection, and $\triangle \mathrm{BC} / \Delta \mathrm{CO}$ here referred to a typical value on a regional scale instead of ratios of one specific emission types. Statistical results of BC and CO concentrations and BC-CO correlation were summarized in Table 1.

For Cluster \#1, the mean $\mathrm{CO}$ and $\mathrm{BC}$ mass concentration was $395.6 \pm 161.9 \mathrm{ppbv}$ and $1357.0 \pm 1173.5 \mathrm{ng} \mathrm{m}^{-3}$ respec- tively, and $\Delta \mathrm{BC} / \Delta \mathrm{CO}$ ratio was $6.5 \pm 0.43 \mathrm{ng} \mathrm{m}^{-3} \mathrm{ppbv}^{-1}$, and the $\mathrm{x}$-intercept of the BC-CO correlation was $184.7 \pm 17.5 \mathrm{ppbv}$; footprint calculations revealed that the pollutions mostly come from Anhui, Henan provinces, and the emission from south part of Shanxi and west part of Shandong provinces also partially contributed to the high pollution loadings in the observation site. Regard to Henan province, over $75 \%$ of $\mathrm{BC}$ emissions were from domestic sector, however the latter only accounted for about $42 \%$ of 
Table 2. The BC-CO relationships in BB pollution dominant episodes.

\begin{tabular}{llrrrrrr}
\hline episode & date & $\begin{array}{r}\text { mean CO } \\
\text { (ppbv) }\end{array}$ & Max. CO & $\begin{array}{r}\text { mean BC } \\
\left(\mathrm{ng} \mathrm{m}^{-3}\right)\end{array}$ & Max. BC & $\begin{array}{r}\Delta \mathrm{BC} / \Delta \mathrm{CO} \\
\left(\mathrm{ng} \mathrm{m}^{-3} \mathrm{ppb}^{-1}\right)\end{array}$ & $\begin{array}{r}\text { Hotspots* } \\
(\mathrm{N})\end{array}$ \\
\hline 1 & 22-23 October 2007 & 448.3 & 630.7 & 2927.6 & 5346.2 & $11.6 \pm 0.5$ & 35 \\
2 & 6-8 January 2008 & 592.1 & 780.3 & 3105.6 & 5573.5 & $10.3 \pm 0.3$ & 812 \\
\hline
\end{tabular}

* statistical results possibly underestimate the total number of hotspots because some fire points are likely blocked by clouds.

CO emissions(Streets et al., 2006). It was the same as the situation in Shanxi province; domestic activities contributed about $63.5 \%$ of BC emission and only $15.5 \%$ of CO emissions respectively, and industry such as coal and chemical production, power generation, and metal refining hold over $47.3 \%$ of $\mathrm{CO}$ emissions, which could have great influence on BC-CO relationship. According to INTEX-B inventory, the mean $\triangle \mathrm{BC} / \triangle \mathrm{CO}$ ratios of anthropogenic emissions were approximately 9.7 and $8.4 \mathrm{ng} \mathrm{m}^{-3} \mathrm{ppbv}^{-1}$ for Henan and Anhui provinces in Standard Temperature and Pressure state, about $39 \%$ higher than our results averagely.

$\mathrm{BC}$ and $\mathrm{CO}$ concentrations from Cluster \#2 had means of $645.1 \mathrm{ng} \mathrm{m}^{-3}$ and $237.0 \mathrm{ppbv}$. Studies at Nanjing (Latitude: $32.1^{\circ} \mathrm{N}$, Longitude: $118.7^{\circ} \mathrm{E}$ ) showed that the yearly mean $\mathrm{CO}$ and NO concentration were $1130 \pm 880 \mathrm{ppbv}$ and $10.6 \pm 24.5 \mathrm{ppbv}$, respectively and the high $\mathrm{CO}$ concentration in Nanjing was attributed to the low traffic speed and the congested traffic in the local urban area and gas/oil consumptions in surrounding industrial areas (Tu et al., 2007). In this study, $\Delta \mathrm{BC} / \Delta \mathrm{CO}$ ratio value was $8.8 \pm 0.9 \mathrm{ng} \mathrm{m}^{-3} \mathrm{ppbv}^{-1}$, comparable to the value (10.1 $\triangle \mathrm{gBC} / \triangle \mathrm{gCO}$, about $8.1 \mathrm{ng} \mathrm{m}^{-3} \mathrm{ppbv}^{-1}$ assuming in STP conditions) obtained in Shanghai mega city (Zhou et al., 2009), and higher than that in Beijing mega city (Han et al., 2009) for $\Delta \mathrm{BC} / \Delta \mathrm{CO}$ ratio ranging from $3.5 \mathrm{ng} \mathrm{m}^{-3} \mathrm{ppbv}^{-1}$ (winter) to $5.8 \mathrm{ng} \mathrm{m}^{-3} \mathrm{ppbv}^{-1}$ (fall). The relatively high $\Delta \mathrm{BC} / \Delta \mathrm{CO}$ ratio from Cluster $\# 2$ mostly resulted from significant contributions of carbonaceous matter from domestic, transportation and industry sources. According to China Energy Statistics Yearbook 2006, percentage of diesel vehicles in Shanghai area was about 2 times higher than that in Beijing, and diesel fuel consumption was even about 5.3 times higher in 2005, even with nearly same gasoline and kerosene (C11-C16) consumption (Zhou et al., 2009). Studies at Tokyo and Beijing urban site also highlighted the significant impact of heavy diesel duty vehicles on $\triangle B C / \Delta C O$ ratios. As a large container port in China the densely shipping and combustion of low-quality bunker fuels in containers and other marine vessels could be another reason for the higher $\triangle \mathrm{BC} / \triangle \mathrm{CO}$ ratio from this Region. Our result was $50 \%$ higher than the $\Delta \mathrm{BC} / \Delta \mathrm{CO}$ ratios of anthropogenic emissions from Jiangsu $\left(6.1 \mathrm{ng} \mathrm{m}^{-3} \mathrm{ppbv}^{-1}\right)$ and Zhejiang $\left(5.9 \mathrm{n} \mathrm{m}^{-3} \mathrm{ppbv}^{-1}\right)$ province in Standard Temperature and Pressure state.
In Cluster \#3, $\mathrm{CO}$ and $\mathrm{BC}$ mass concentrations of air masses arriving at the study site were $285.8 \pm 122.8 \mathrm{ppbv}$ and $740.9 \pm 849.0 \mathrm{ng} \mathrm{m}^{-3}$ respectively. Footprint analysis demonstrated that pollution emission from northern Jiangxi and northwestern of Fujian provinces substantially contributed to high $\mathrm{BC}$ and $\mathrm{CO}$ loading at the site. The $\Delta \mathrm{BC} / \Delta \mathrm{CO}$ ratio had a mean of $6.5 \pm 0.2 \mathrm{ng} \mathrm{m}^{-3} \mathrm{ppbv}^{-1}$, relatively lower than the $\triangle \mathrm{BC} / \triangle \mathrm{CO}$ ratios derived from inventory $\left(9.0 \mathrm{ng} \mathrm{m}^{-3} \mathrm{ppbv}^{-1}\right.$ for Fujian provinces and $7.8 \mathrm{ng} \mathrm{m}^{-3} \mathrm{ppbv}^{-1}$ for Jiangxi province).

\section{Characteristics in open biomass burning cases}

Combining with hotspots information detected by MODIS and CALIPSO satellites, two cases when biomass burning played a dominant role on high $\mathrm{BC}$ mass concentrations were selected. Table 2 summarized statistic results of $\mathrm{BC}$ and $\mathrm{CO}$ mass concentrations, and the $\mathrm{BC}-\mathrm{CO}$ scatter plots for two cases were shown in Fig. 5. As shown, High Pearson correlation coefficient $(R>0.9)$ for each episode were observed. All RH of air masses were less than $40 \%$ along 48-hour back trajectories, indicating that the loss of $\mathrm{BC}$ during the transport could be minor. On October 2223 (Case 1), air masses were nearly stagnant south of the observation site (Fig. 6), and 35 hotspots were confidently detected by the MODIS satellite. CALIPSO satellite results also indicated heavy "smoke" plumes at a $2-3 \mathrm{~km}$ altitude distributed over $25^{\circ} \mathrm{N}-30^{\circ} \mathrm{N}$ in Southern China (Fig. 6b). $\mathrm{CO}$ and $\mathrm{BC}$ mass concentrations significantly increased to $2927.6 \pm 1354.5 \mathrm{ng} \mathrm{m}^{-3}$, the maximum BC concentration even reached to $5346.2 \mathrm{ng} \mathrm{m}^{-3}$, and the mean $\Delta \mathrm{BC} / \Delta \mathrm{CO}$ was $11.6 \pm 0.5 \mathrm{ng} \mathrm{m}^{-3} \mathrm{ppbv}^{-1}$, which was comparable those reported for Texas that $\Delta \mathrm{BC} / \Delta \mathrm{CO}$ exceeded $9 \mathrm{ng} \mathrm{kg}^{-1} \mathrm{ppbv}^{-1}$ (equal to $11.1 \mathrm{ng} \mathrm{m}^{-3} \mathrm{ppbv}^{-1}$ assuming air density of $1.25 \mathrm{~kg} \mathrm{~m}^{-3}$ ) in biomass burning plumes (Spackman et al., 2008). On 6-8 January 2008 (Case 2) another biomass burning influencing episode was observed. More than 800 hotspots in surrounding regions were detected by MODIS, and more than 60 cities exceeded the class 2 limit value $\left(150 \mu \mathrm{g} \mathrm{m}^{-3}\right.$ daily) of the National Ambient Air Quality Standard. Daily $\mathrm{PM}_{10}$ mass concentrations in urban areas along the air mass back trajectories were $182.2 \mu \mathrm{g} \mathrm{m}^{-3}$ (on 6 January) and $220.0 \mu \mathrm{g} \mathrm{m}^{-3}$ (on 8 January). According to vertical profile information 
Table 3. Relationship between the $\Delta \mathrm{BC} / \Delta \mathrm{CO}$ ratio and $\mathrm{RH}$ for all data.

\begin{tabular}{|c|c|c|c|c|c|c|c|c|c|}
\hline \multicolumn{3}{|c|}{$\begin{array}{l}\mathrm{RH}^{\mathrm{a}} \\
(\%)\end{array}$} & \multicolumn{2}{|c|}{$\begin{array}{c}\mathrm{BC} \\
\left(\mathrm{ng} \mathrm{m}^{-3}\right)\end{array}$} & \multicolumn{2}{|c|}{$\begin{array}{c}\mathrm{CO} \\
(\mathrm{ppbv})\end{array}$} & \multicolumn{2}{|c|}{$\begin{array}{c}\Delta \mathrm{BC} / \Delta \mathrm{CO} \\
\left(\mathrm{ng} \mathrm{m}^{-3} \mathrm{ppbv}^{-1}\right)\end{array}$} & \multirow[t]{2}{*}{$\mathrm{N}^{\mathrm{b}}$} \\
\hline Range & Mean & Std. & Mean & Std. & Mean & Std. & Mean & Std. & \\
\hline$>70$ & 78.6 & 5.0 & 359.0 & 334.2 & 393.2 & 162.0 & 0.1 & 0.1 & 6500 \\
\hline $70 \sim 40$ & 57.6 & 4.3 & 1543.1 & 636.5 & 439.6 & 106.2 & 5.4 & 1.3 & 1340 \\
\hline$<40$ & 25.0 & 19.7 & 856.6 & 951.2 & 309.4 & 133.6 & 7.2 & 0.5 & 13900 \\
\hline
\end{tabular}

${ }^{\mathrm{a}} \mathrm{RH}$ is the mean value for episodes when meteorology along air mass pathways meet with the required RH condition. ${ }^{\mathrm{b}}$ Number of min averaged data points.

provided by CALIPSO observations, the pollution in the $25^{\circ} \mathrm{N}-32^{\circ} \mathrm{N}$ latitude range was related to "smoke" and "polluted continental" plumes (Fig. 6d), and the aerosol optical depth at $550 \mathrm{~nm}$ observed by MODIS in this region exceeded 0.9 (http://gdata1.sci.gsfc.nasa.gov/daac-bin/G3/gui. cgi?instance_id=aerosol_daily). Mean $\mathrm{BC}$ and $\mathrm{CO}$ concentrations were $3105.6 \mathrm{\mu g} \mathrm{m}^{-3}$ and $592.2 \mathrm{ppbv}$ respectively, and the $\Delta \mathrm{BC} / \Delta \mathrm{CO}$ ratio was $10.3 \pm 0.3 \mathrm{ng} \mathrm{m}^{-3} \mathrm{ppbv}^{-1}$. According to footprint analysis, open biomass burning events mostly occurred in Hunan and Jiangxi provinces where over $32.9 \%$ and $10.7 \%$ of crop residues were burned outdoors annually (2007 Rural statistical Yearbook of China), and unhusked rice and ramie were their major commercial crops there. Observations in India indicated strong BC emissions during the forest fire season, with a $\Delta \mathrm{BC} / \Delta \mathrm{CO}$ ratio of 28.5 $\left(\mu \mathrm{g} \mathrm{m}^{-3}\right) /\left(\mu \mathrm{g} \mathrm{m}^{-3}\right)$ (Badarinath et al., 2007), much higher than our results. The types of burning mass and combustion conditions could be of great importance to investigate the $\mathrm{BC}-\mathrm{CO}$ relationship.

\section{BC loss rate on $\mathrm{RH}$}

As mentioned above, major uncertainties of $\Delta \mathrm{BC} / \Delta \mathrm{CO}$ ratio came from rain washout and the dry deposition processes (they collide or absorb with other hydrophilic substances, gradually grew larger in the higher RH environment, and subsequently were removed from atmosphere according to gravitational settling and turbulence transportation) of $\mathrm{BC}$ particles. To highlight the loss rate of $\mathrm{BC}$ on $\mathrm{RH}$, the relationship between $\triangle \mathrm{BC} / \Delta \mathrm{CO}$ ratio and $\mathrm{RH}$ was presented. Figure 7 showed scatter plot of the $\Delta \mathrm{BC} / \Delta \mathrm{CO}$ ratio on $\mathrm{RH}$ in the absent of rain along transportation path. For better expression, $\mathrm{RH}$ was divided into three ranges $(\mathrm{RH}>70 \%$, $70 \%>\mathrm{RH}>40 \%$ and $\mathrm{RH}<40 \%$ ), and only $\mathrm{BC}$ data that met the required $\mathrm{RH}$ criterion for the entire air mass pathway were used in calculations. Statistical results for each cluster were summarized in Table 3 . The Table showed that more than $90 \%$ of $\mathrm{BC}$ could become hygroscopic as a result of coagulation and aging processes and was lost during the $48 \mathrm{~h}$ transport. The linear fitting result showed that the dependency of $\Delta \mathrm{BC} / \Delta \mathrm{CO}$ ratio on $\mathrm{RH}$ have slope of -0.13 ,

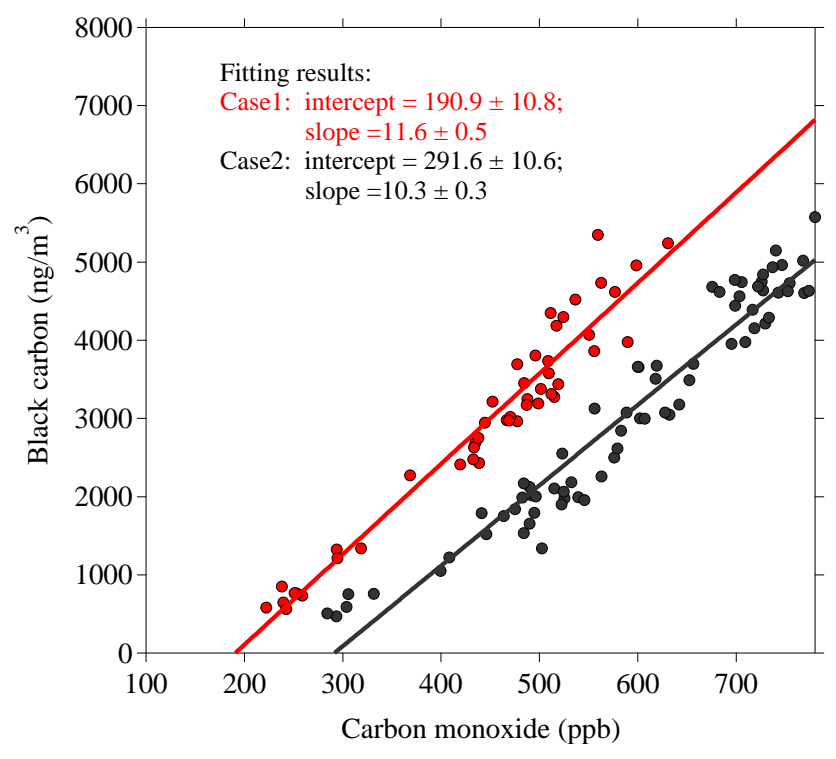

Fig. 5. Scatterplot and linear regression results of the BC-CO correlation during biomass burning episodes. Cases 1 (red) represents the episode on 22-23 October 2007 and Case 2 (black) for 6 January $\sim 8$ 2007.

-0.15 and -0.10 for Cluster \#1, Cluster\#2 and Cluster \#3. As shown in Fig. 7, the BC loss rate of air masses from Eastern China Region (Cluster \#2, red line) was slightly larger than that from Cluster \#1 (black line) and Cluster \#3 (blue line). The coating compounds such as water-soluble inorganic salts (e.g., sulfate and nitrate) and organic carbon matters were the key factors in determining the final removing efficiency of BC. Observation showed that secondary pollution in Shanghai mostly resulted from significant increase of sulfate and nitrate aerosol which were oxidized from anthropogenic $\mathrm{SO}_{2}$ and $\mathrm{NO}_{2}$ owing to high atmospheric oxidation ability in urban area (Du et al., 2011), supporting our discussion. Correspondingly higher proportion of water soluble inorganic matters for aged aerosol particles could also be the possible explanation of quick removing rate of $\mathrm{BC}$ from Cluster \#2. Previous study also indicated that secondary organic carbon accounted for a high portion of the total organic 

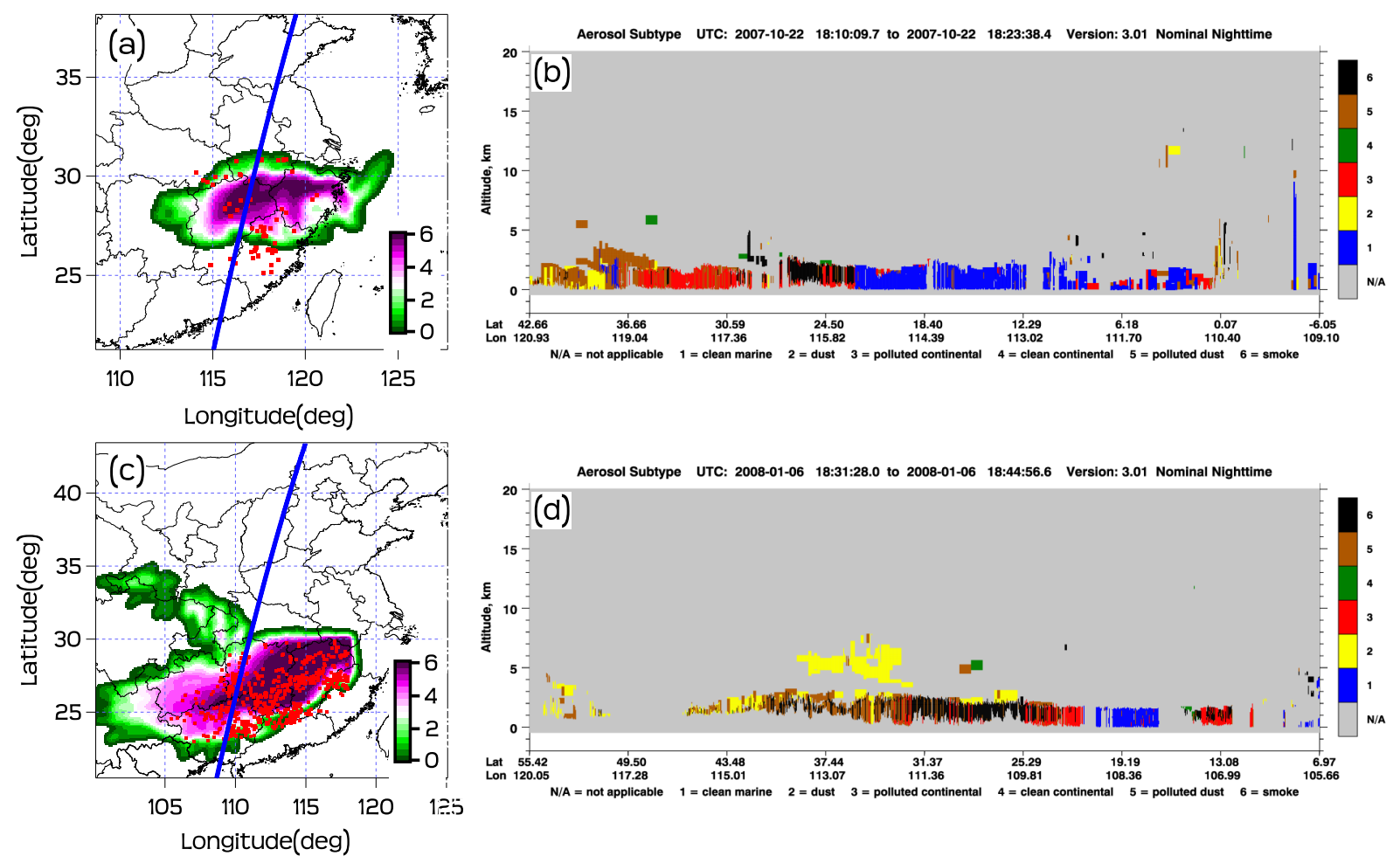

Fig. 6. Footprint regions of air masses and hotspots detected by MODIS satellite for open-burning events. Left panels indicate the spatial distribution of hotspots (red cross), air mass footprint region (shading color is in unit of natural logarithm of residence hour in each grid), and orbit of CALIPSO satellite (blue line); Right panels show the vertical profile of aerosol types along the CALIPSO satellite orbit, Black color blocks indicate the "smoke" aerosols are presented. (a) (b) for Case 1, and (c) $\sim(\mathbf{d})$ for Case 2.

matters in $\mathrm{PM}_{2.5}$ particulate matters throughout whole observation period at downtown of Shanghai city (Yang et al., 2005), and about $30 \%$ of the total carbon was water soluble, and unresolved complex mixture and fatty acids were the most abundant components quantified in solvent extractable organic compounds in Shanghai city (Feng et al., 2006). Besides, the high proportion of primary organic matter (normally hydrophobic) in the $\mathrm{PM}_{2.5}$ category from southeast China than that from Eastern China might be another reason for a lower loss rate of aerosol particles for Cluster \#3 (Han et al., 2008).

\section{Comparison with other studies and discussions}

Table 4 listed $\triangle \mathrm{BC} / \Delta \mathrm{CO}$ ratios measured by some previous studies in different regions, and variations in the $\triangle \mathrm{BC} / \triangle \mathrm{CO}$ ratio for urban plumes and burning biomass were observed. For urban plumes, observations of the $\triangle \mathrm{BC} / \triangle \mathrm{CO}$ ratio have not always agreed well from region to region owing to the diverse mixture of emission sources. According to footprint analysis, the $\triangle B C / \triangle C O$ ratio of urban plumes in Yangtze River Delta Region was $8.8 \pm 0.9 \mathrm{ng} \mathrm{m}^{-3} \mathrm{ppbv}^{-1}$, larger than the results $(\Delta \mathrm{BC} / \Delta \mathrm{CO}$ ratio of $\left.5.7 \pm 0.14 \mathrm{ng} \mathrm{m}^{-3} \mathrm{ppbv}^{-1}\right)$ reported in Tokyo area
(Kondo et al., 2006), and that $\left(3.5 \sim 5.8 \mathrm{ng} \mathrm{m}^{-3} \mathrm{ppbv}^{-1}\right)$ in Beijing area (Han et al., 2009). Their studies emphasized the intake air temperature dependence of vehicles engines on $\mathrm{BC}$ and $\mathrm{CO}$ emissions, and $\mathrm{CO}$ emissions would increase during the warming-up of a vehicle under cold conditions when the temperature of the catalyst was not sufficiently high. As mentioned in Section 4 relatively higher $\triangle \mathrm{BC} / \Delta \mathrm{CO}$ ratio in Cluster $\# 2$ could be attributed to high percentage of diesel vehicles of on-road transportation and less-combustion efficiency containers handling equipment and marine vessels in this region. An observational study (Zhou et al., 2009) performed in both Beijing and Shanghai mega cities with Aethalometer (Magee Scientifc, Berkeley, California, USA, Model AE-21) showed that the $\Delta \mathrm{BC} / \Delta \mathrm{CO}$ ratio (10.1 $\Delta \mathrm{gBC} / \Delta \mathrm{gCO}$, about $8.1 \mathrm{ng} \mathrm{m}^{-3} \mathrm{ppbv}^{-1}$ assuming in STP conditions) from Shanghai was over twice higher than that $\left(3.0 \mathrm{ng} \mathrm{m}^{-3} \mathrm{ppbv}^{-1}\right)$ in Beijing urban areas, supporting our conclusion. Recent studies using DRI2001A carbonaceous aerosol analyzer (with IMPROVE protocol) in Taiwan reported a spatially averaged $\triangle \mathrm{BC} / \Delta \mathrm{CO}$ value of $5.3 \mathrm{ng} \mathrm{m}^{-3} \mathrm{ppbv}^{-1}$ (Chou et al., 2010). Bottom-up statistical method (INTEX-B emission inventory 2006) showed that the mean $\triangle \mathrm{BC} / \triangle \mathrm{CO}$ ratios of anthropogenic emissions were approximately $4.1 \mathrm{ng} \mathrm{m}^{-3} \mathrm{ppbv}^{-1}$ for the Yangtze River Delta 
Table 4. Comparisons with results of other observation studies.

\begin{tabular}{|c|c|c|c|c|c|}
\hline Location & Study period & $\begin{array}{l}\mathrm{EC} / \mathrm{CO} \text { ratio } \\
\mathrm{ng} \mathrm{m}^{-3} \mathrm{ppbv}^{-1}\end{array}$ & Instrument & Method & References \\
\hline Beijing & All seasons, 2005-2006 & $3.5-5.8$ & $\begin{array}{l}\text { Semi-continuous ECOC } \\
\text { analyzer, RT3052, NIOSH }\end{array}$ & TOT & Han et al. (2009) \\
\hline Beijing & Summer, 2005 & 3.7 & $\begin{array}{l}\text { Aethalometer, Magee Scientifc, } \\
\text { Model AE- } 21\end{array}$ & Opt1 & Zhou et al. (2009) \\
\hline Shanghai & & 10.1 & & & \\
\hline Guangzhou & October, November 2004 & $7.9 \pm 0.2$ & $\begin{array}{l}\text { Thermal/optical aerosol carbon } \\
\text { analyzer, NIOSH }\end{array}$ & TOT & Andreae et al. (2006) \\
\hline Tokyo & All seasons 2003-2005 & $5.7 \pm 1.4$ & $\begin{array}{l}\text { Semi-continuous ECOC } \\
\text { analyzer, RT3052, NIOSH }\end{array}$ & TOT & Kondo et al. (2006) \\
\hline Taiwan & All seasons 2003-2007 & 5.3 & $\begin{array}{l}\text { DRI2001A carbonaceous } \\
\text { aerosol analyzer, IMPROVE }\end{array}$ & TOR & Chou et al. (2010) \\
\hline Mexico & March 2006 & $2.89 \pm 0.89$ & Single particle soot photometer & LII & Subramanian et al. (2010) \\
\hline Texas & End of summer 2006 & $7.2 *$ & Single particle soot photometer & LII & Spackman et al. (2008) \\
\hline Europe & April-September 2008 & 0.8 to 6.2 & Single particle soot photometer & LII & McMeeking et al. (2010) \\
\hline \multirow{3}{*}{ Mt.Huangshan } & All seasons 2007 & 6.5 for $\mathrm{NCP}$ & multiple-angle absorption & Opt2 & This study \\
\hline & & 8.8 for ECR & photometer, Model 5012 & & \\
\hline & & $10.3 \sim 11.6$ for $\mathrm{BB}$ & & & \\
\hline
\end{tabular}

TOT: thermal optical transmittance;

Opt1: converted from values in unit of $\mathrm{BC}\left(\mu \mathrm{g} \mathrm{m}^{-3}\right) / \mathrm{CO}\left(\mu \mathrm{g} \mathrm{m}^{-3}\right)$, absorption of light at a wavelength of $880 \mathrm{~nm}$, and $\mathrm{BC}$ concentration (with a $\pm 50 \%$ error) reported here didn't rule out the interference from light scattering by aerosol components and the filter matrix owing lack of universal correction method available.

TOR: thermal optical reflectance;

LII: laser-induced incandescence;

Opt2: absorption of light at a wavelength of $637 \mathrm{~nm}$, and influence from multi-scattering effects were taken into consideration.

*: converted from ng BC ( $\mathrm{kg}$ dry air $)^{-1}(\mathrm{ppb} \mathrm{CO})^{-1}$ assuming air density of $1.25 \mathrm{~kg} \mathrm{~m}^{-3}$ in STP stats.

NCP: North China Plain; ECR: Eastern China Regions; BB: Biomass Burning.

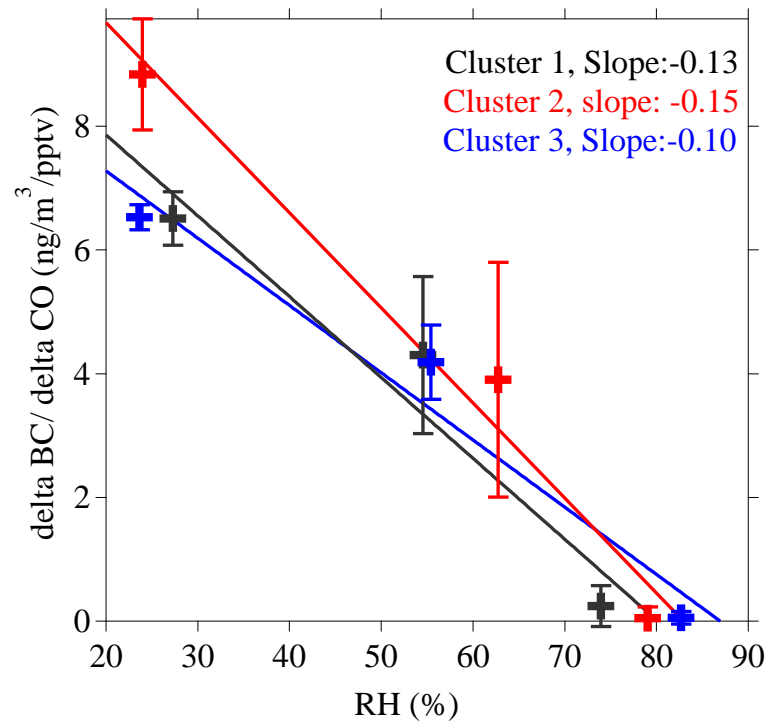

Fig. 7. Dependence of the observed $\Delta \mathrm{BC} / \Delta \mathrm{CO}$ ratio on $\mathrm{RH}$ at Mt. Huang for all non-rain periods. Relationships between $\Delta \mathrm{BC} / \Delta \mathrm{CO}$ and $\mathrm{RH}$ are fitted by linear regression method. The black, red and blue lines represent for Cluster \#1, Cluster \#2 and Cluster \#3, respectively.

region, about $50 \%$ lower than the our results. McMeeking et al. (2010) pointed out that the $\Delta \mathrm{BC} / \Delta \mathrm{CO}$ ratio in $\mathrm{Eu}-$ rope urban plumes ranged from 0.8 to $6.2 \mathrm{ng} \mathrm{m}^{-3} \mathrm{ppbv}^{-1}$, and the highest $\triangle \mathrm{BC} / \triangle \mathrm{CO}$ ratio was observed for the areas classified as far-outflow and background (ratio of $\mathrm{O}_{3} / \mathrm{NO}_{\mathrm{x}}>10$ ), where air masses were more chemically processed. This attribution highlights the importance of emission sources over $\mathrm{BC}$ or $\mathrm{CO}$ processing and removal mechanisms (McMeeking et al., 2010). In the present work, the $\triangle \mathrm{BC} / \triangle \mathrm{CO}$ ratio for episodes of burning biomass were $12.4 \pm 1.5 \mathrm{ng} \mathrm{m}^{-3} \mathrm{ppbv}^{-1}$, comparable to the measurements for Texas (Spackman et al., 2008) and values reported for regions in India (Dickerson et al., 2002). Regional Emission inventory in Asia also reported $\triangle \mathrm{BC} / \Delta \mathrm{CO}$ ratios of 11.0 , 11.2, 11.8, 11.4 and $11.0 \mathrm{ng} \mathrm{m}^{-3} \mathrm{ppbv}^{-1}$ for open burning of crop residue in Anhui, Hebei, Henan, Jiangsu and Shandong provinces respectively (Yamaji et al., 2010). Owing to such large observed variations and uncertainties concerning the photochemical processing, great concern should be taken when implementing evaluating emission inventories, and more comprehensive analyses of carbonaceous chemical and physical properties were urgently needed.

\section{Conclusions}

The $\mathrm{BC}$ mass concentration and $\mathrm{CO}$ mixing ratio were measured at the summit of Mt. Huang from June 2006 to May 2009 to investigate the BC-CO relationship of urban plumes from different regions in Eastern China. The seasonal variation in the $\mathrm{BC}$ concentration had a bimodal distribution with a minimum in summer and two peaks in May 
and October, when there was large-scale burning of crop residues. The $\mathrm{CO}$ concentration increased sharply in the winter "heating period" in Northern China, and the yearly mean $\mathrm{BC}$ and $\mathrm{CO}$ concentrations were $1004.5 \pm 895.5 \mathrm{ng} \mathrm{m}^{-3}$ and $424.1 \pm 159.2$ ppbv respectively. At Mt. Huang, $\Delta \mathrm{BC} / \Delta \mathrm{CO}$ ratio showed slightly unimodal diurnal variations, with maxima during the day (09:00-17:00 LST) and minima at night (21:00-04:00 LST) owing to the uplift of pollution with the transport of valley breeze and PBL development during the day and intrusions of clean air from the upper troposphere at night. Cluster analysis using data for which the ambient $\mathrm{RH}$ was less than $40 \%$ for the whole 48 hour back trajectories indicated that the $\triangle \mathrm{BC} / \Delta \mathrm{CO}$ ratios of plumes from northern, eastern and southern regions of China were $6.5 \pm 0.4$, $8.8 \pm 0.9$ and $6.5 \pm 0.2 \mathrm{ng} \mathrm{m}^{-3} \mathrm{ppbv}^{-1}$ respectively. Two biomass burning cases were presented in this study, and the $\Delta \mathrm{BC} / \Delta \mathrm{CO}$ ratios were $10.3 \pm 0.3 \mathrm{ng} \mathrm{m}^{-3} \mathrm{ppbv}^{-1}$ and $11.6 \pm 0.5 \mathrm{ng} \mathrm{m}^{-3} \mathrm{ppbv}^{-1}$. Furthermore, the loss of $\mathrm{BC}$ during transport was also estimated on the basis of the $\triangle \mathrm{BC} / \triangle \mathrm{CO}-\mathrm{RH}$ relationship along air mass pathways. Results showed that $\mathrm{BC}$ can be significantly scavenged when air mass traveled under higher $\mathrm{RH}$ conditions for 2 days and linear fitting result indicated that the slope of $\triangle \mathrm{BC} / \triangle \mathrm{CO}-\mathrm{RH}$ relationship for Eastern China was $-0.15 \mathrm{ng} \mathrm{m}^{-3} \mathrm{ppbv}^{-1} \%^{-1}$, which implying a quick loss rate of $\mathrm{BC}$ than that from other regions $\left(-0.13 \mathrm{ng} \mathrm{m}^{-3} \mathrm{ppbv}^{-1} \%^{-1}\right.$ and $-0.10 \mathrm{ng} \mathrm{m}^{-3} \mathrm{ppbv}^{-1} \%^{-1}$ for northern, and southern parts of China). Coatings of aged particles by water soluble compound from this Region would be the most likely explanations.

Acknowledgements. The authors would like to thank all staff of the meteorological station at Mt. Huang for providing lots of conveniences in daily instrument maintenance and data requisition during the observations. We gratefully acknowledge the anonymous reviewers and many Japanese researchers, Hisahiro Takashima, Fumikazu Taketani at the JAMSTEC for their helpful comments and suggestions. This work was supported by National Basic Research 973 project (2010CB4951804) and NSFC grant (40775077) and the Global Environment Research Fund (S-7, C-081, B-051) by the Ministry of the Environment, Japan.

Edited by: M. Kopacz

\section{References}

Adachi, K., Chung, S., and Buseck, P.: Shapes of soot aerosol particles and implications for their effects on climate, J. Geophys. Res. , 115(D15), D15206, doi:10.1029/2009JD012868, 2010.

Andreae, M. O. and Gelencsér, A.: Black carbon or brown carbon? The nature of light-absorbing carbonaceous aerosols, Atmos. Chem. Phys., 6, 3131-3148, doi:10.5194/acp-6-3131-2006, 2006.

Babu, S. S., Satheesh, S. K., and Moorthy, K. K.:, Aerosol radiative forcing due to enhanced black carbon at an urban site in India,
Geophys. Res. Lett., 29(18), 4 pp., doi:10.1029/2002GL015826, 2002.

Badarinath, K. V. S. and Latha, K. M.: Direct radiative forcing from black carbon aerosols over urban environment, Adv. Space Res., 37(12), 2183-2188, 2006.

Badarinath, K. V. S., Kharol, S. K., Chand, T. R. K., Parvathi, Y. G., Anasuya, T., and Jyothsna, A. N.: Variations in black carbon aerosol, carbon monoxide and ozone over an urban area of Hyderabad, India, during the forest fire season, Atmos. Res., 85(1), 18-26, 2007.

Baumgardner, D., Raga, G., Peralta, O., Rosas, I., Castro, T., Kuhlbusch, T., John, A., and Petzold, A.: Diagnosing black carbon trends in large urban areas using carbon monoxide measurements, J. Geophys. Res.-Atmos., 107, doi:10.1029/2001JD000626, 2002.

Bond, T. C., Streets, D. G., Yarber, K. F., Nelson, S. M., Woo, J.-H., and Klimont, Z.: A technology-based global inventory of black and organic carbon emissions from combustion, J. Geophys. Res., 109(D14), D14203, doi:10.1029/2003jd003697, 2004.

Cao, G. L., Zhang, X. Y., and Zheng, F. C.: Inventory of black carbon and organic carbon emissions from China, Atmos. Environ., 40(34), 6516-6527, 2006.

Cao, J. J., Zhu, C. S., Chow, J. C., Watson, J. G., Han, Y. M., Wang, G. H., Shen, Z. X., and An, Z. S.: Black carbon relationships with emissions and meteorology in Xi' an, China, Atmos. Res., 94(2), 194-202, 2009.

Chen, Y. J., Zhi, G. R., Feng, Y. L., Liu, D. Y., Zhang, G., Li, J., Sheng, G. Y., and Fu, J. M.: Measurements of Black and Organic Carbon Emission Factors for Household Coal Combustion in China: Implication for Emission Reduction, Environ. Sci. Technol., 43(24), 9495-9500, 2009.

Chou, C. C.-K., Lee, C. T., Cheng, M. T., Yuan, C. S., Chen, S. J., Wu, Y. L., Hsu, W. C., Lung, S. C., Hsu, S. C., Lin, C. Y., and Liu, S. C.: Seasonal variation and spatial distribution of carbonaceous aerosols in Taiwan, Atmos. Chem. Phys., 10, 9563-9578, doi:10.5194/acp-10-9563-2010, 2010.

Chow, J. C., Watson, J. G., Doraiswamy, P., Chen, L. W. A., Sodeman, D. A., Lowenthal, D. H., Park, K., Arnott, W. P., and Motallebi, N.: Aerosol light absorption, black carbon, and elemental carbon at the Fresno Supersite, California, Atmos. Res., 93(4), 874-887, 2009.

Chung, S. H. and Seinfeld, J. H.: Climate response of direct radiative forcing of anthropogenic black carbon, J. Geophys. Res.Atmos., 110(D11), 25 pp., doi:10.1029/2004JD005441, 2005.

Conant, W. C., Nenes, A., and Seinfeld, J. H.: Black carbon radiative heating effects on cloud microphysics and implications for the aerosol indirect effect - 1. Extended Kohler theory, J. Geophys. Res.-Atmos., 107(D21), 4604, doi:10.1029/2002JD002094, 2002.

Cooke, W. F. and Wilson, J. J. N.: A global black carbon aerosol model, J. Geophys. Res., 101(D14), 19395-19409, doi:10.1029/96jd00671, 1996.

Cozic, J., Mertes, S., Verheggen, B., Cziczo, D. J., Gallavardin, S. J., Walter, S., Baltensperger, U., and Weingartner, E.: Black carbon enrichment in atmospheric ice particle residuals observed in lower tropospheric mixed phase clouds, J. Geophys. Res.Atmos., 113(D15209), doi:10.1029/2007JD009266, 2008.

Croft, B., Lohmann, U., and von Salzen, K.: Black carbon ageing in the Canadian Centre for Climate modelling and 
analysis atmospheric general circulation model, Atmos. Chem. Phys., 5(7), 1931-1949, doi:10.5194/acp-5-1931-2005, 2005.

Derwent, R. G., Ryall, D. B., Jennings, S. G., Spain, T. G., and Simmonds, P. G.: Black carbon aerosol and carbon monoxide in European regionally polluted air masses at Mace Head, Ireland during 1995-1998, Atmos. Environ., 35(36), 6371-6378, 2001.

Dickerson, R. R., Andreae, M. O., Campos, T., Mayol-Bracero, O. L., Neusuess, C., and Streets, D. G.: Analysis of black carbon and carbon monoxide observed over the Indian Ocean: Implications for emissions and photochemistry, J. Geophys. Res.Atmos., 107(D19), 8017, doi:10.1029/2001JD000501, 2002.

Du, H. H., Kong, L. D., and Chen, T. T.: Insights into summertime haze pollution events over Shanghai based on online watersoluble ionic composition of aerosols, Atmos. Environ., 45(29), 5131-5137, 2011.

Feng, J., Chan, C. K., Chan, M., Fang, M., Hu, L., He, X., and Tang, X. Y.: Characteristics of organic matter in $\mathrm{PM}_{2.5}$ in Shanghai, Chemosphere, 64(8), 1393-1400, 2006.

Han, Z., Zhang, R., Wang, Q. G., Wang, W., Cao, J., and $\mathrm{Xu}, \mathrm{J}$.: Regional modeling of organic aerosols over China in summertime, J. Geophys. Res., 113(D11), D11202, doi:10.1029/2007jd009436, 2008.

Han, S., Kondo, Y., Oshima, N., Takegawa, N., Miyazaki, Y., Hu, M., Lin, P., Deng, Z., Zhao, Y., Sugimoto, N., and Wu, Y.: Temporal variations of elemental carbon in Beijing, J. Geophys. Res., 114(D23), D23202, doi:10.1029/2009jd012027, 2009.

Hitzenberger, R., Petzold, A., Bauer, H., Ctyroky, P., Pouresmaeil, P., Laskus, L., and Puxbaum, H.: Intercomparison of thermal and optical measurement methods for elemental carbon and black carbon at an urban location, Environ. Sci. Technol., 40(20), 6377-6383, 2006.

Jacobson, M. Z.: Strong radiative heating due to the mixing state of black carbon in atmospheric aerosols, Nature, 409(6821), 695-697, http://www.nature.com/nature/journal/v409/n6821/ suppinfo/409695a0_S1.html, 2001.

Jennings, S. G., Spain, T. G., Doddridge, B. G., Maring, H., Kelly, B. P., and Hansen, A. D. A.: Concurrent measurements of black carbon aerosol and carbon monoxide at Mace Head, J. Geophys. Res.-Atmos., 101(D14), 19447-19454, 1996.

Kanaya, Y., Komazaki, Y., Pochanart, P., Liu, Y., Akimoto, H., Gao, J., Wang, T., and Wang, Z.: Mass concentrations of black carbon measured by four instruments in the middle of Central East China in June 2006, Atmos. Chem. Phys., 8, 7637-7649, doi:10.5194/acp-8-7637-2008, 2008.

Kondo, Y., Komazaki, Y., Miyazaki, Y., Moteki, N., Takegawa, N., Kodama, D., Deguchi, S., Nogami, M., Fukuda, M., and Miyakawa, T.: Temporal variations of elemental carbon in Tokyo, J. Geophys. Res, 111, D12205, doi:10.1029/2009JD012027, 2006.

Kondo, Y., Sahu, L., Kuwata, M., Miyazaki, Y., Takegawa, N., Moteki, N., Imaru, J., Han, S., Nakayama, T., Oanh, N. T. K., Hu, M., Kim, Y. J., and Kita, K.: Stabilization of the Mass Absorption Cross Section of Black Carbon for Filter-Based Absorption Photometry by the use of a Heated Inlet, Aerosol Sci. Technol., 43(8), 741-756, 2009.

Kuwata, M., Kondo, Y., and Takegawa, N.: Critical condensed mass for activation of black carbon as cloud condensation nuclei in Tokyo, J. Geophys. Res.-Atmos., 114, D20202, 9 pp., doi:10.1029/2009JD012086, 2009.
Li, C., Marufu, L. T., Dickerson, R. R., Li, Z., Wen, T., Wang, Y., Wang, P., Chen, H., and Stehr, J. W.: In situ measurements of trace gases and aerosol optical properties at a rural site in Northern China during East Asian Study of Tropospheric Aerosols: An International Regional Experiment 2005, J. Geophys. Res., 112(D22), D22S04, doi:10.1029/2006jd007592, 2007.

Li, J., Wang, Z., Akimoto, H., Yamaji, K., Takigawa, M., Pochanart, P., Liu, Y., Tanimoto, H., and Kanaya, Y.: Nearground ozone source attributions and outflow in central Eastern China during MTX2006, Atmos. Chem. Phys., 8, 7335-7351, doi:10.5194/acp-8-7335-2008, 2008.

Liu, X. H., Penner, J. E., and Wang, M. H.: Influence of anthropogenic sulfate and black carbon on upper tropospheric clouds in the NCAR CAM3 model coupled to the IMPACT global aerosol model, J. Geophys. Res.-Atmos., 114, D03204, doi:10.1029/2008JD010492,, 2009.

McMeeking, G. R., Hamburger, T., Liu, D., Flynn, M., Morgan, W. T., Northway, M., Highwood, E. J., Krejci, R., Allan, J. D., Minikin, A., and Coe, H.: Black carbon measurements in the boundary layer over western and northern Europe, Atmos. Chem. Phys., 10, 9393-9414, doi:10.5194/acp-10-9393-2010, 2010.

Ming, J., Cachier, H., Xiao, C., Qin, D., Kang, S., Hou, S., and $\mathrm{Xu}, \mathrm{J}$.: Black carbon record based on a shallow Himalayan ice core and its climatic implications, Atmos. Chem. Phys., 8, 13431352, doi:10.5194/acp-8-1343-2008, 2008.

Ming, J., Xiao, C. D., Cachier, H., Qin, D. H., Qin, X., Li, Z. Q., and $\mathrm{Pu}$, J. C.: Black Carbon (BC) in the snow of glaciers in west China and its potential effects on albedos, Atmos. Res., 92(1), 114-123, 2009.

Naoe, H., Hasegawa, S., Heintzenberg, J., Okada, K., Uchiyama, A., Zaizen, Y., Kobayashi, E., and Yamazak, A.: State of mixture of atmospheric submicrometer black carbon particles and its effect on particulate light absorption, Atmos. Environ., 43(6), 1296-1301, 2009.

Nenes, A., Conant, W. C., and Seinfeld, J. H.: Black carbon radiative heating effects on cloud microphysics and implications for the aerosol indirect effect -2 . Cloud microphysics, J. Geophys. Res.-Atmos., 107(D21), 4605, 2002.

Oberdörster, G. and Yu, C.: The carcinogenic potential of inhaled diesel exhaust: a particle effect?, J. Aerosol Sci., 21, S397-S401, 1990.

Ohara, T., Akimoto, H., Kurokawa, J., Horii, N., Yamaji, K., Yan, X., and Hayasaka, T.: An Asian emission inventory of anthropogenic emission sources for the period 19802020, Atmos. Chem. Phys., 7, 4419-4444, doi:10.5194/acp-7-4419-2007, 2007.

Pan, X. L., Yan, P., Tang, J., Ma, J. Z., Wang, Z. F., Gbaguidi, A., and Sun, Y. L.: Observational study of influence of aerosol hygroscopic growth on scattering coefficient over rural area near Beijing mega-city, Atmos. Chem. Phys., 9, 7519-7530, doi:10.5194/acp-9-7519-2009, 2009.

Petzold, A., Schloesser, H., Sheridan, P. J., Arnott, W. P., Ogren, J. A., and Virkkula, A.: Evaluation of Multiangle Absorption Photometry for Measuring Aerosol Light Absorption, Aerosol Sci. Technol., 39(1), 40-51, 2005.

Qu, W. J., Arimoto, R., Zhang, X. Y., Zhao, C. H., Wang, Y. Q., Sheng, L. F., and Fu, G.: Spatial distribution and interannual variation of surface PM10 concentrations over eightysix Chinese cities, Atmos. Chem. Phys., 10, 5641-5662, 
doi:10.5194/acp-10-5641-2010, 2010.

Ramana, M. V., V. Ramanathan, Y. Feng, S. C. Yoon, S. W. Kim, G. R. Carmichael, and J. J. Schauer, Warming influenced by the ratio of black carbon to sulphate and the black-carbon source, Nature Geosci, 3(8), 542-545, 2010.

Ramanathan, V., and Carmichael, G.: Global and regional climate changes due to black carbon, Nat. Geosci., 1(4), 221-227, 2008.

Reisinger, P., Wonaschutz, A., Hitzenberger, R., Petzold, A., Bauer, H., Jankowski, N., Puxbaum, H., Chi, X., and Maenhaut, W.: Intercomparison of measurement techniques for black or elemental carbon under urban background conditions in wintertime: Influence of biomass combustion, Environ. Sci. Technol., 42(3), 884 889,2008

Sato, M., Hansen, J., Koch, D., Lacis, A., Ruedy, R., Dubovik, O., Holben, B., Chin, M., and Novakov, T.: Global atmospheric black carbon inferred from AERONET, P. Natl. A. Sci., 100(11), 6319-6324, 2003.

Schwarz, J. P., Spackman, J. R., Fahey, D. W., Gao, R. S., Lohmann, U., Stier, P., Watts, L. A., Thomson, D. S., Lack, D. A., Pfister, L., Mahoney, M. J., Baumgardner, D., Wilson, J. C., and Reeves, J. M.: Coatings and their enhancement of black carbon light absorption in the tropical atmosphere, J. Geophys. Res.-Atmos., 113(D3), D03203, doi:10.1029/2007JD009042, 2008.

Seinfeld, J.: Atmospheric science-Black carbon and brown clouds, Nat. Geosci., 1(1), 15-16, 2008.

Slowik, J. G., Cross, E. S., Han, J. H., Davidovits, P., Onasch, T. B., Jayne, J. T., Williams, L. R., Canagaratna, M. R., Worsnop, D. R., Chakrabarty, R. K., Moosmuller, H., Arnott, W. P., Schwarz, J. P., Gao, R. S., Fahey, D. W., Kok, G. L., and Petzold, A.: An inter-comparison of instruments measuring black carbon content of soot particles, Aerosol Sci. Technol., 41(3), 295-314, 2007.

Spackman, J. R., Schwarz, J. P., Gao, R. S., Watts, L. A., Thomson, D. S., Fahey, D. W., Holloway, J. S., de Gouw, J. A., Trainer, M., and Ryerson, T. B.: Empirical correlations between black carbon aerosol and carbon monoxide in the lower and middle troposphere, Geophys. Res. Lett., 35(19), L19816, doi:10.1029/2008GL035237, 2008.

Streets, D. G. and Aunan, K.: The importance of China's household sector for black carbon emissions, Geophys. Res. Lett., 32(12), L12708, doi:10.1029/2005GL022960, 2005.

Streets, D. G., Gupta, S., Waldhoff, S. T., Wang, M. Q., Bond, T. C., and Bo, Y. Y.: Black carbon emissions in China, Atmos. Environ., 35(25), 4281-4296, 2001.
Streets, D. G., Zhang, Q., Wang, L., He, K., Hao, J., Wu, Y., Tang, Y., and Carmichael, G. R.: Revisiting China's CO emissions after the Transport and Chemical Evolution over the Pacific (TRACE-P) mission: Synthesis of inventories, atmospheric modeling, and observations, J. Geophys. Res. , 111(D14), D14306, doi:10.1029/2006JD007118, 2006.

Subramanian, R., Kok, G. L., Baumgardner, D., Clarke, A., Shinozuka, Y., Campos, T. L., Heizer, C. G., Stephens, B. B., de Foy, B., Voss, P. B., and Zaveri, R. A.: Black carbon over Mexico: the effect of atmospheric transport on mixing state, mass absorption cross-section, and $\mathrm{BC} / \mathrm{CO}$ ratios, Atmos. Chem. Phys., 10, 219-237, doi:10.5194/acp-10-219-2010, 2010.

Thevenon, F., Anselmetti, F. S., Bernasconi, S. M., and Schwikowski, M.: Mineral dust and elemental black carbon records from an Alpine ice core (Colle Gnifetti glacier) over the last millennium, J. Geophys. Res.-Atmos., 114, D17102, doi:10.1029/2008JD011490, 2009.

Tu, J., Xia, Z. G., Wang, H., and Li, W.: Temporal variations in surface ozone and its precursors and meteorological effects at an urban site in China, Atmos. Res., 85(3-4), 310-337, 2007.

Wang, Z., Li, J., Wang, X., Pochanart, P., and Akimoto, H.: Modeling of regional high ozone episode observed at two mountain sites (Mt. Tai and Huang) in East China, J. Atmos. Chem., 55(3), 253-272, 2006.

Yamaji, K., Li, J., Uno, I., Kanaya, Y., Irie, H., Takigawa, M., Komazaki, Y., Pochanart, P., Liu, Y., Tanimoto, H., Ohara, T. Yan, X., Wang, Z., and Akimoto, H.: Impact of open crop residual burning on air quality over Central Eastern China during the Mount Tai Experiment 2006 (MTX2006), Atmos. Chem. Phys., 10, 7353-7368, doi:10.5194/acp-10-7353-2010, 2010.

Yang, F., He, K., Ye, B., Chen, X., Cha, L., Cadle, S. H., Chan, T., and Mulawa, P. A.: One-year record of organic and elemental carbon in fine particles in downtown Beijing and Shanghai, Atmos. Chem. Phys., 5, 1449-1457, doi:10.5194/acp-5-1449-2005, 2005.

Zhang, Q., Streets, D. G., Carmichael, G. R., He, K. B., Huo, H., Kannari, A., Klimont, Z., Park, I. S., Reddy, S., Fu, J. S., Chen, D., Duan, L., Lei, Y., Wang, L. T., and Yao, Z. L.: Asian emissions in 2006 for the NASA INTEX-B mission, Atmos. Chem. Phys., 9, 5131-5153, doi:10.5194/acp-9-5131-2009, 2009.

Zhou, X., Gao, J., Wang, T., Wu, W., and Wang W.: Measurement of black carbon aerosols near two Chinese megacities and the implications for improving emission inventories, Atmos. Environ. 43(25), 3918-3924, 2009. 